\title{
Lisa Lampert-Weissig, Medieval Literature and Postcolonial Studies
}

\section{Alistair Fox}

\section{Q OpenEdition}

1 Journals

Electronic version

URL: https://journals.openedition.org/ces/7932

DOI: $10.4000 /$ ces.7932

ISSN: 2534-6695

Publisher

SEPC (Société d'études des pays du Commonwealth)

\section{Printed version}

Date of publication: 1 September 2011

Number of pages: 103-104

ISSN: 2270-0633

\section{Electronic reference}

Alistair Fox, "Lisa Lampert-Weissig, Medieval Literature and Postcolonial Studies", Commonwealth Essays and Studies [Online], 34.1 | 2011, Online since 16 November 2021, connection on 01 December 2021 URL: http://journals.openedition.org/ces/7932 ; DOI: https://doi.org/10.4000/ces.7932

This text was automatically generated on 1 December 2021.



Commonwealth Essays and Studies is licensed under a Licence Creative Commons Attribution - Pas d'Utilisation Commerciale - Pas de Modification 4.0 International. 


\title{
Lisa Lampert-Weissig, Medieval Literature and Postcolonial Studies
}

\author{
Alistair Fox
}

\section{REFERENCES}

Lisa Lampert-Weissig. Medieval Literature and Postcolonial Studies. Edinburgh: Edinburgh UP, 2010. 188 p. ISBN (pb): $9780748637188 . £ 19.99$

1 Lisa Lampert-Weissig's Medieval Literature and Postcolonial Studies is the fourth volume to appear in a Postcolonial Literary Studies Series published by the Edinburgh University Press, which aims to show how the preoccupations and theoretical assumptions of postcolonial studies have produced a reconfiguration of the major periods and areas of literature. It might seem that medieval studies and postcolonial studies are worlds apart, but Lampert-Weissig argues, to the contrary, that they have exerted an important reciprocal influence on one another. On one hand, postcolonial theory has influenced the reading of medieval texts and contexts, while on the other hand, medievalists have provided important critiques of key concepts in postcolonial studies, such as orientalism, nation, race, and hybridity. Furthermore, she insists, the uniting of medieval and postcolonial studies remedies the neglect by postcolonial studies of premodern texts and contexts by showing the historical roots of certain issues in the contemporary world that postcolonial scholars are exploring. Such is the importance of this reciprocal interchange, she claims, that Postcolonial Medieval Studies is now an acknowledged part of medieval literary scholarship, especially in the United States. To back up her contentions, Lampert-Weissig presents a number of detailed case studies, and surveys significant books published during the past decade showing the effects of the influence of postcolonial studies on scholarly writing concerning the Middle Ages.

How convincing is this argument, and what interest might it hold for scholars either of postcolonial studies, or medieval studies? Lampert-Weissig frankly admits that the attempt to bring the two fields together has been viewed as problematic by those who 
believe, like Gabrielle Spiegel, that it is a mistake to try and superimpose contemporary theories "on periods and persons for which they were never designed and to which they simply do not apply" (249-50). Nevertheless, the author convincingly demonstrates how the decentring gaze of postcolonial studies has led to new perspectives on Eurocentrism, has raised questions about periodisation, and has promoted new thinking about borders and boundaries which has broadened the scope of medieval studies by encouraging scholars to look beyond Europe, and to focus on neglected or marginalised areas, such as Iberian Arabic literature. She is equally convincing in showing how the complex socio-political and cultural situations identified within medieval studies raise questions about the viability of key concepts, such as orientalism and hybridity; for example, the complex hybrid cultures found in the medieval Crusader states, in medieval Iberia and Norman Sicily, turn out not to fit the mechanism of Orientalist discourse, thereby exposing the inadequacy of the binarism at the heart of Said's formulation. She is also persuasive in suggesting the presence of "contemporary medievalisms" as forces influencing current events, such as the "Islam in Europe" debate, which cannot be fully understood without a sense of the medieval past of "Christian Europe" and the "othering" that this has produced.

In summary, Lisa Lampert-Weissig has produced a bold exposition of the reciprocal relevance of postcolonial and medieval studies, written in a clear style that should make this book very useful in the classroom for outlining the parameters of that relevance. Whether or not postcolonial studies can be applied more closely to the study of medieval literature in any practical sense remains to be seen.

\section{AUTHORS}

\section{ALISTAIR FOX}

Alistair Fox is Professor of English and Director of the Centre for Research on National Identity at the University of Otago. He has written extensively on humanism, politics, and reform in early modern England, and his current research focuses on New Zealand cultural identity, with his two most recent books being The Ship of Dreams: Masculinity in Contemporary New Zealand Fiction (2008), and Jane Campion: Authorship and Personal Cinema (2011). 